\title{
ROLE OF THE INTERPRETATION RESERVE IN THE CONSTITUTIONALIZATION OF ROMANIAN AND FRENCH CRIMINAL LAW
}

\section{A. Iftimiei}

\author{
Andra Iftimiei \\ Law Faculty \\ "Alexandru Ioan Cuza" University of Iași \\ *Correspondence: Andra Iftimiei, Alexandru Ioan Cuza University of Iași, Law Faculty, Carol I \\ Blvd, no. 11, Iași, Romania \\ E-mail: andra.iftimiei@uaic.ro
}

\begin{abstract}
The interpretation reserve is the only instrument through which the criminal judge becomes an actor in the constitutionalization process of the criminal law, because although he does not rejoice from the competence of rendering decisions the on constitutionality or unconstitutionality of law, the interpretation under reserve directly refers to it, by the compulsoriness of observing the sense granted by the constitutional court.
\end{abstract}

Keywords: interpretation reserve, constituionalization, criminal law, comparate law.

\section{Introduction}

Depending on the instance of occurrence of the interpretative decision with interpretation reserve, the role of the constitutional court is altered: if the interpretation reserve occurs before the entering into force of a law, the constitutional judge is placed between the legislative elaboration of the text and its application by the law court ${ }^{1}$. Accordingly, the constitutional courts have a vocation in choosing and guiding the legislator's criminal policy, the direct outcome being the integration of interpretative decisions in criminal law sources.

In Romania, from the viewpoint of the legal force, the decisions issued with interpretation reserve have the same force, their compulsoriness for the future having as legal grounds Art. 147 of the Romanian Constitution.

By interpretation reserve, in France, one understands the technique through which the Constitutional Council indicates in advance how a legislative provision should be interpreted so as not to violate the Constitution ${ }^{2}$. In Romania, the decisions with interpretation reserve are those decisions of the Constitutional Court by which, without declaring the non-constitutionality, the Court ascertains which is the interpretation that would lead to non-constitutionality and through which one carries out the interpretation compatible with the fundamental $\mathrm{Law}^{3}$. Upon the moment of entering into force of the Constitution in 1958, in France, the interpretation reserve used by the constitutional judge is conceived only before the entering into force of the law, but together with the amendment of the Fundamental Law and with the introduction of the $a$. posteriori constitutional control, the technique of interpretation reserve was triggered also in the case of the crucial issue of constitutionality. Hence, the distinctions between the two states have also disappeared regarding the use of the interpretation reserve, thus the Decision no. 2 of the Constitutional Council must be included in the broader sphere of interpretation reserve, in the

\footnotetext{
${ }^{1}$ G. Royer, "La réserve d'interprétation constitutionnelle en droit criminel" in Revue de sciences criminelles, no. 4/2008, p. 829.

${ }^{2}$ Decision 2 DC of June 17, 18 and 24, 1959.

${ }^{3}$ V. M. Ciobanu, „Considerations regarding the decisions that can be pronounced following the exercise of constitutionality control" in Dreptul, no. 5-6/1994, p. 21.
} 


\section{ROLE OF THE INTERPRETATION RESERVE IN THE CONSTITUTIONALIZATION}

OF ROMANIAN AND FRENCH CRIMINAL LAW

sense that, by this use, in both types of control, one ensures legal security by discovering the advantage to declare the partial conformity of a criminal provision to the detriment of its elimination from the sphere of the legislative asset. Accordingly, both in Romania and France, there emerges a third mean of expression of the constitutional judge: besides the admission and rejection decision, there emerged the decision under interpretation reserve (the French Constitutional Council very quickly understood the use of this technique in the posterior control, aspect reflected in the 26 decisions with interpretation reserve rendered only from March 2010 to September $2011^{4}$ ).

From the perspective of French law, there are three categories of interpretation reserves ${ }^{5}$ : neutralizing interpretation reserves, consisting in the confinement of the litigation disposition of any legal effect or in the forbiddance of interpretations that would become unconstitutional; constructive interpretation reserves that assume the addition to a law of some definitions in order to achieve conformity with the rights and freedoms guaranteed by the Constitution; directive interpretation reserves, directly referring to the authorities responsible with the application of the law, indicating the direction that has to be conferred to the legislative provision in question. The Romanian constitutional litigation department acknowledges the same categories of decisions with interpretation reserve endowed with the same final scope, nevertheless preferring a slightly distinct terminology: neutralizing decisions; additive decisions and appeal-decisions ${ }^{6}$.

The interpretation reserve is the only instrument through which the criminal judge becomes an actor in the constitutionalization process of the criminal law, because although he does not rejoice from the competence of rendering decisions the on constitutionality or unconstitutionality of a law, the interpretation under reserve directly refers to it, by the compulsoriness of observing the sense granted by the constitutional court. Hence, the criminal judge is the receiver of the decisions issued by the constitutional court, demanding him to guarantee the constitutional application of the provision in question?

\section{The interpretation Reserve in Romanian Constitutional Jurisprudence}

In the constitutional jurisprudence of Romania, the interpretation reserve is emphasized in the enactment terms of the decision of the Constitutional Court by the formulation "the provisions are unconstitutional to the extent in which ...", following that the subsequent part should equally provide the solution for applying in full constitutionality. Consequently, the Constitutional Court becomes an actor in the process of constitutionalization by conditioning constitutionality to a certain interpretative direction.

In the Decision no. 81 of 15 July $1994^{8}$, pertaining to the exception of unconstitutionality of the provisions of Art.200 paragraph (1) of the Romanian Criminal Code, theRomanian Constitutional Court decided that the litigation court has not only the right, but also the obligation to interpret the Constitution in order to erradicate the discrepancy between the internal text and the European text.

Prevailing from the possibility of declaring conformity under interpretation reserve, the Constitutional Court admits in part the exception of unconstitutionality and determines that the provisions of paragraph (1) of Art. 200 Romanian Criminal Code are unconstitutional to the extent in which they to the sexual relations between adults of the same text, with mutual consent, which are not performed in public or which do not produce public scandal. Accordingly, the Court indirectly directs, in the enactment terms, the interpretation according to the Constitution,

\footnotetext{
${ }^{4}$ E. Cartier (dir.), La QPC, le procès et ses juges. L'impact sur le procès et l'architecture juridictionnelle, ed. Dalloz, Paris, 2013, p. 309.

${ }^{5}$ Idem, pp. 310-311.

${ }^{6}$ B. Selejan-Guțan, Exception of unconstitutionality, ed. 2, ed. C. H. Beck, Bucharest, 2010, pp. 231-233.

${ }^{7}$ D. Rebut, „Le juge pénal face aux exigences constitutionnelles” in Cahiers du Conseil Constitutionnel, no. 16 (Dossier: le Conseil Constitutionnel et les divers branches du droit), June 2004, article consulted on the website www.conseil-constitutionnel.fr, on November 13, 2013.

${ }^{8}$ Published in the Official Gazette no. 14 of January 25, 1995.
} 


\section{A. Iftimiei}

so that Art.200 paragraph (1) should not be fully deprived of effects; thus, on the grounds of the decisions, we admit the interpretation per a contrario, according to which any relations with minors or among adults, but by constraint, must be maintained under criminal repression. We considered that the interpretation reserve lead to the constitutionalization of criminal law by reconfiguring the criminal framework of offences against sex life; following this decision, the legislator realized that the interpretation granted by the Court is circumscribed to the definition of rape, so that it exonerated the sexual relations between persons of the same sex.

Through the interpretation reserve expressed in Decision no. 25 of 6 March $1996^{9}$ regarding offences against authorities, one established the sense of application of Art.238 of the Romanian Criminal Code - Offences against authorities, with direct reference to the passive subject of the offence. The text of Art.238 of Romanian Criminal Code referred to Art.160 of the Romanian Criminal Code: one punished the offense brought to the detriment of one's honor, threatening, hitting or any violence acts committed in public, against one of the persons provided under Art.160 of the Romanian Criminal Code; in this last article we provide the person fulfilling an important state or public activity.

The alteration of the constitutional regime and the lack of forecast on behalf of the criminal legislator lead to the situation in which the inconsistency between the Fundamental Law and Art.238 by reference to Art.160 of Criminal Law becomes visible, accordingly the notice is grounded. The inconsistency had in view the quality of the passive subject, who was a person fulfilling an important state or public activity. The analysis of the constitutional provisions emphasized the fact that the fundamental law recognizes as social value only the state authority, not the public authority. On these grounds, the Court determined that the provisions of Art.238 of the Romanian Criminal Code remain in force only to the extent in which the incriminated facts refer to a person fulfilling an important state activity. By interpretation reserve, the Court registers in the jurisprudence catalogue a new neutralizing decision, annihilating the effect of the provision which was not updated after the exercise of the original constituent power in 1991.

The Romanian Constitutional Court expressed interpretation reserves either in the decision terms or in the exposition of grounds. An illustration where the interpretation reserve was given to ground a decision is Decision no. 19 of 8 March $1993^{10}$, regarding the settlement of the exception of unconstitutionality of the provisions of Art.902 of Romanian Criminal Code and Art.50 paragraph (1) letter. e) of the Decree no. 244/1978. In order to avoid the lack of regulation and the consequences that could inherently result, the Court considers itself entitled to, until adopting some new regulations in this respect, to grant, to the text which are challenged before it, that interpretation that is harmonized with the Romanian Constitution.

With regard to Art.302 of the Romanian Criminal Code the text incriminates the performance, without authorization, of any acts or actions that, according to the legal provisions, are considered operations of import, export or transit. Consequently, referring to Art.25 letter c) and Art.50 paragraph 1 letter c) of the Decree no. 244/1978, establishing the following as offence: "the selling and buying of precious metals, precious and semi-precious stones, natural stones as well as intermediation of these transactions" and, reporting only to this type of operations with jewelry, to the same extent in which one is obliged to invoke exception of unconstitutionality, the Court reckons that the texts would be unconstitutional if they were interpreted further on in the way that the operations with jewelry - selling, buying, intermediation - can be conducted only by economic agents with state capital.

Thus, the Court interprets the texts in the sense that any economic agent may carry out such operations with jewelry if they are mentioned in the object of activity and the company is licensed - provided this is so - according to law, the above mentioned texts having, under current circumstances, the role to stop those that do not possess such licenses and try to elude the special instituted regime regarding precious metals and stones, as well as other legal provisions such as tax provisions or those regulating the merchants' professional duties.

\footnotetext{
${ }^{9}$ Published in the Official Gazette no. 324 of December 4, 1996.

${ }^{10}$ Published in the Official Gazette no. 105 of May 24, 1993.
} 


\section{ROLE OF THE INTERPRETATION RESERVE IN THE CONSTITUTIONALIZATION \\ OF ROMANIAN AND FRENCH CRIMINAL LAW}

The amendment of the criminal law in Romania, by recodification, did not absolve the constitutional court to render decisions on certain provisions of the ancient criminal law. An illustration in this respect is the Decision of the Romanian Constitutional Court no. $78 / 2014^{11}$ pertaining to the exception of unconstitutionality of the provisions of Art.118 paragraph (2) letter a) of the Romanian Criminal Code of 1969.

The object of the intimation is the measure of extended confiscation - a standard of material criminal law, which was introduced in the Romanian legislation by Law no. 63/2012 for the amendment and completion of the Romanian Criminal Code and of Law no. 286/2009 regarding the Romanian Criminal Code, published in the Official Journal no. 258/2012, a law transposing in the national legislation Art. 3 of Framework Decision 2005/212/JAI of the Council of 24 February 2005, pertaining to the confiscation of products, means and goods related to offence, published in the Official Journal of the European Union series L 68 of March 15, 2005. The analysis of the Romanian Constitutional Court has as starting point the viewpoints expressed by the authors of the exception, according to which the provisions of Art. $118^{2}$ paragraph (2) letter a) of the Romanian Criminal Code of 1969 affect the principle of applying the more favorable criminal law and equality of citizens before the law, in the sense that it is retroactive, being discriminatingly applicable to the deeds committed under the provisions of the ancient law.

The Romanian Court ascertains that, by its effects, extended confiscation, although not conditioned by criminal responsibility, assumes an indissoluble connection with crime. As a consequence, it appears as a cause of removing a state of danger and of prevention for committing some other criminal act.

Analyzing the content of the entire regulation regarding extended confiscation of the Romanian Criminal Code, the Romanian Court ascertains that the principle of the more favorable criminal law is equally applicable to this institution.

With regard to the principle of equality before the law of the citizens, the Court ascertains that it is possible that a co-author be definitively trialed based on the ancient legislation and, as a consequence, the Court might not order the taking of the safety measure of extended confiscation, while regarding the other co-author who is still under legal proceedings, the court might inflict such a measure. Consequently, in the extent to which the more favorable criminal law would not be opposable, the latter would have discriminated regarding the aspect of the legal treatment without disposing of reasonable and objective grounds as compared to the first. In other words, the provisions regarding extended confiscation are constitutional to the extent in which they apply only to the act committed based on the new legislative solution that intervened from the moment of entering into force of Law no. 63/2012, respectively on 22 April 2012.

Regarding the criminal procedural law, the constitutional court issued an interpretation reserve in Decision no. 67 of 13 February 2003, pertaining to the exception of unconstitutionality of the provisions of Art.40 paragraph 2 of the Romanian Criminal Procedure Code ${ }^{12}$. The object of the exception of unconstitutionality is represented by the provisions of Art.40 paragraph 2 of the Romanian Criminal Procedure Code, which have the following content: "Gaining of quality after committing the crime does not determine the change of competence."

To support the exception of unconstitutionality, its author invoked the violation of the provisions of Art.16 paragraph (1) and of Art.69 paragraph (1) of the Constitution, which have the following content: Art.16 paragraph (1): "The citizens are equal before the law and before public authorities, without privileges and without discrimination."; Art.69 paragraph (1): “The deputy or senator cannot be detained, arrested, searched or sued, criminally or contraventionally without the consent of the Chamber he/she belongs to, after his/her hearing. The judicial competence belongs to the Supreme Court of Justice."

\footnotetext{
${ }^{11}$ Published in the Official Gazette of Romania no. 273/2014.

${ }^{12}$ Published in the Official Gazetteof Romania no. 178 of March 21, 2003.
} 


\section{A. Iftimiei}

The Romanian Constitutional Court ascertains that the provisions of Art.40 paragraph 2 of the Romanian Criminal Procedure Code are unconstitutional to the extent in which they are understood and applied in the way that senators and deputies will be judged by other courts than the Supreme Court of Justice in the cases in which the apprehension of the court took place before the date of obtaining the mandate of parliamentarian.

\section{The Interpretation Reserve in the French Constitutional Jurisprudence}

The French Constitutional Council used the technique of interpretation reserve in criminal law for the first time in the contents of Decision no. 80-127 DC regarding the law of strengthening security and protecting the liberty of persons ${ }^{13}$. Although the constitutional judge does not expressly highlight that the decision also comprises an interpretation reserve, this is obvious since the law in question incriminated the acts of using any means in order to hinder or restrain the traffic of motor vehicles. The French Constitutional Council considered that this incrimination did not regard persons legally exercising the right to strike recognized by the Constitution, even though interruption of their work has the effect of disturbing or suppressing the traffic of motor vehicles. Hence, the constitutional court favorably approves the conformity with the fundamental law but without bringing prejudice to the legal right to strike; the constitutional interpretation has the aim to guarantee the balance of constitutional principles between them.

Before the French Constitutional Council there were raised both issues of the unconstitutionality of the criminal law - special part, as well as from the criminal law - general part. Consequently, Decision no. 2011 - 164 QPC of September $2011^{14}$ has as the object the responsibility of a producer of on-line websites. The criticized provisions stated that "in case one of the offences provided under section IV of the law regarding the freedom of the press are committed by an electronic means of public communication, the manager of the publication or the co-manager will be criminally investigated as main author if the message in question was the object of a prior public communication". In this case, the author of the message will be investigated as an accomplice.

The authors of the intimation consider that the invoked provisions violate the principle of equality before the criminal law, since the manager is responsible as the author of the offence, while the proper editor of the message is considered only the accomplice, sense in which the penalty will be softer. The interpretation reserve enounced by the Constitutional Council has in view the possibility of keeping the anonymity of the one who sent the message on the internet, a case in which the criminal responsibility of the creator or administrator of a public communication website will be retained only if he was aware of the contents of the message before posting it online. Again, the constitutional judge indicates the way in which the challenged provision should be interpreted, making estimations also on the way of its application by retaining the criminal responsibility only if the subjective side of the offence is proved.

A recent illustration takes into consideration Decision no. 2014-690 DC of 13 March $2014^{15}$, according to which the law regarding consumption was subject to constitutionality verification, via the means of an a priori control. From the point of view of the topic subject to analysis, we are interested only in certain provisions subject to control, respectively those

\footnotetext{
${ }^{13}$ Consulted on the website http://www.conseil-constitutionnel.fr/conseilconstitutionnel/francais/les-decisions/acces-par-date/decisions-depuis-1959/1981/80-127dc/decision-n-80-127-dc-du-20-janvier-1981.7928.html, on April 17, 2014.

${ }^{14}$ Consulted on the website http://www.conseil-constitutionnel.fr/conseilconstitutionnel/francais/les-decisions/acces-par-date/decisions-depuis-1959/2011/2011164-qpc/decision-n-2011-164-qpc-du-16-septembre-2011.99672.html, on April 17, 2014.

${ }^{15}$ Consulted on the website http://www.conseil-constitutionnel.fr/conseilconstitutionnel/francais/les-decisions/acces-par-date/decisions-depuis-1959/2014/2014690-dc/decision-n-2014-690-dc-du-13-mars-2014.140273.html, on April 15, 2014.
} 
referring to Art.130 of the law which amends several articles of the Consumption Code by roughening the criminal sanctions it provides. If the authors of the intimation would that the modification of sanctions has a disproportional character and could endanger the activity of enterprises.

The French Constitutional Council (CCF) assessed that through themselves, criminal sanctions have no disproportional character; however, if an administrative sanction is susceptible of combination with a criminal sanction, the proportionality principle assumes that, irrespectively of the case, all rendered sanctions should not exceed the highest quantum of one of the applied sanctions. This way, it is the competence of related administrative and legal authorities to watch for the observance of these exigencies. Thus, the French constitutional court draw attention on the ways through which the criticized provisions would become unconstitutional. If, in their essence, criminal sanctions do not reveal any reason of unconstitutionality, their application may create a violation of the principle of penalty proportionality.

The interpretation reserve was used by the French constitutional judge equally in the contents of the CCF Decision no. 96-377 DC of 16 July $1996^{16}$, regarding the law of tightening the repressions against terrorism and prejudices of persons acting on behalf of public authorities or with attributions in the sphere of public service similar to those of legal police. The option of the French constitutional council is at least interesting, since it declares that Art.10 does not observe the French Constitution, but if the measure aims for investigations in flagrant cases, then this is the only case when the provision is in conformity with the Fundamental Law.

Article 10 brings changes to Art.706-24 of the French Criminal Procedure Code, in the way that for offences of terrorism searches, visits and monitoring can be carried out even during night time. The nature of such provisions is to prejudice individual freedom, since they do not set out an hourly schedule in which home search should be conducted, for instance. Consequently, the interpretative intervention of the constitutional judge constitutionalizes the provision because he endows it with the possibility of application only in a certain background, respectively that of flagrant.

The CCF Decision no. 2014-693 of 25 March $2014^{17}$, regarding the law referring to geolocalization was a new subject for the constitutional court to render on some aspect of criminal law, using the technique of interpretation reserve.

The text challenged before the French Council provided that the term of 10 days in which the person subject to investigation or the assisted witness can challenge the appeal at the procedure provided under Art.230-40 begins with the date when the contents of the geolocalization operations were made aware, operations carried out as stipulated by the law. Art.230-40 sets out the conditions according to which the judge of rights and freedoms can authorize certain information not to appear in the investigation file related to installation and withdrawal of the technical mean of geolocalization or the recording of localization data and of elements allowing the identification of a person.

Taking into account the complexity of the investigation related to criminality and organized delinquency, the above provisions should be interpreted only as allowing the passing of the term of 10 days before the decision of the judge of rights and liberties be made aware, formally, to the person subject to investigation or to the assisted witness.

\footnotetext{
${ }^{16}$ Consulted on the website http://www.conseil-constitutionnel.fr/conseilconstitutionnel/francais/les-decisions/acces-par-date/decisions-depuis-1959/1996/96-377dc/decision-n-96-377-dc-du-16-juillet-1996.10816.html, on April 15, 2014.

${ }^{17}$ Consulted on the website http://www.conseil-constitutionnel.fr/conseilconstitutionnel/francais/les-decisions/acces-par-date/decisions-depuis-1959/2014/2014693-dc/decision-n-2014-693-dc-du-25-mars-2014.140345.html, on April 16, 2014.
} 


\section{A. Iftimiei}

Reference decision in the French constitutional jurisprudence, also known as Integral veil, decision no. 2010-613 DC $^{18}$ envisaged the reconciliation between public order and individual liberty. The articles subject to the constitutionality control provided that "nobody can, in public space, wear an outfit destined to dissimulate the appearance", except the cases in which the outfit is prescribed or authorized by legislative or regulating provisions, if it is justified by reasons of health or professional reasons, or if it is within sport practices, holiday practices or for artistic or traditional manifestations. Violation of these provisions is punished with the fine provided for second class contraventions.

The reserve of the French Constitutional Council refers to the fact that the interdiction of dissimulating appearance in public space is not meant to restrain the exercise of religious freedom in places of worship opened to the public. By this neutralizing interpretation, the Council subscribed its own jurisprudence to the conventional one and, moreover, allowed the reconciliation between the idea of freedom and public space. The constitutionalization of criminal law emerges from the fact that, by observing the decision of $\mathrm{CCF}$, a safety climate is provided which derives from the observance of public order, mainly in the current background of threats of the terrorist type.

\section{Conclusion}

The interpretation reserve represents the main way for the constitutionalization of the criminal law. Mainly, because the constitutional judges, by their jurisprudence, are part of the criminal policy as they are in charge with the guidance of this kind of policy. When the interpretation reserve is formulated, the constitutional judge, Romanian or French, shows which is the constitutional sense of the legal text and provides the constitutional limits for for proper framing of the provisions of criminal law.

\section{Bibliography:}

- E. Cartier (dir.), La QPC, le procès et ses juges. L'impact sur le procès et l'architecture juridictionnelle, ed. Dalloz, Paris, 2013;

- P. Gaïa, Les grandes décisions du Conseil constitutionnel, $17^{\mathrm{e}}$ édition, ed. Dalloz, Paris, 2013;

- Bianca Selejan-Guțan, Exception of unconstitutionality, ed. 2, ed. C. H. Beck, Bucharest, 2010;

- G. Royer, "La réserve d'interprétation constitutionnelle en droit criminel" in Revue de sciences criminelles, no. 4/2008;

- D. Rebut, „Le juge pénal face aux exigences constitutionnelles” in Cahiers du Conseil Constitutionnel, no. 16 (Dossier: le Conseil Constitutionnel et les divers branches du droit), June 2004, article consulted on the website www.conseil-constitutionnel.fr, on November 13, 2013;

- V. M. Ciobanu, „Considerations regarding the decisions that can be pronounced following the exercise of constitutionality control" in Dreptul, no. 5-6/1994.

* ,This work was supported by the strategic grant POSDRU/159/1.5/S/141699, Project ID 141699, co-financed by the European Social Fund within the Sectorial Operational Program Human Resourses Development 2007-2013" 